\title{
Detection of potential fungal pathogens Fusarium falciforme and $F$. keratoplasticum in unhatched loggerhead turtle eggs using a molecular approach
}

\author{
Jennifer Brofft Bailey, Morgan Lamb, Madalynn Walker, Charriz Weed, \\ Kathryn Stephenson Craven*
}

Georgia Southern University-Armstrong campus, Department of Biology, 11935 Abercorn Street, Savannah, Georgia 31419, USA

\begin{abstract}
The recognition of the Fusarium solani species complex (FSSC) as a potential global threat to sea turtle eggs represents yet another instance of an emerging fungal infection impacting wildlife. Traditionally, culturing has been used to identify fungi associated with sea turtle eggs. Since culturing recovers only a subset of environmental microbes, a molecular approach was adopted instead to survey the fungal composition inside unhatched eggs. DNA was directly extracted from the embryonic fluid and biofilms in 73 fully incubated unhatched loggerhead sea turtle eggs collected from different regions of Jekyll Island, GA, USA, in 2010 and 2012. The fungal internal transcribed spacer region of the nuclear ribosomal DNA (ITS nrDNA) was amplified from the DNA samples, and ITS products were cloned, sequenced and subjected to phylogenetic analysis. Sequences corresponded to previously cultivated fungi and were dominated by the FSSC members Fusarium falciforme and F. keratoplasticum. These fungi were consistently detected in unhatched eggs throughout Jekyll Island during each nesting year examined. Fusarium falciforme and $F$. keratoplasticum ITS sequences were nearly identical to isolates implicated in causing disease in sea turtle embryos from Ascension Island, Australia, Central America and Cape Verde. This represents the first survey establishing these fungal groups in North American loggerhead eggs and provides confirmation of the widespread distribution of $F$. falciforme and $F$. keratoplasticum using a novel approach. As we begin to meet conservation goals of species recovery, density-dependent management issues such as emerging fungal infections become a growing concern. Assessing the long-term impacts of Fusarium may be a rising priority.
\end{abstract}

KEY WORDS: Fusarium solani species complex · Fusarium keratoplasticum · Fusarium falciforme · Loggerhead sea turtles $\cdot$ Embryo mortality $\cdot$ Culture independent $\cdot$ Georgia, USA

\section{INTRODUCTION}

Emerging fungal infections in wild populations are increasingly recognized as a source of disease-driven loss of biodiversity (Fisher et al. 2012). Fungal epidemics in plants have been well documented (Anderson et al. 2004), and fungal infections in animal pop-

${ }^{*}$ Corresponding author: kcraven@georgiasouthern.edu ulations are now gaining recognition on the same scale (Debourgogne et al. 2016). Chytridiomycosis in amphibians and white nose syndrome (WNS) in bats are 2 high-profile examples of such outbreaks in terrestrial ecosystems, and fungal infections have also taken a toll in marine communities (Gleason et al. 2017). Infections of filamentous fungi in bats and

(C) The authors 2018. Open Access under Creative Commons by Attribution Licence. Use, distribution and reproduction are unrestricted. Authors and original publication must be credited. 
amphibians appear more common during life stages that are particularly sensitive (such as metamorphosis), at times of high population density or when individuals are in close proximity (i.e. hibernation and reproduction; Eskew \& Todd 2013). For sea turtles, the stage in their life history meeting these criteria occurs in the nest environment.

During incubation, sea turtle embryos face numerous co-occurring threats: predation, root penetration, flooding, erosion, habitat destruction, pollution, poaching and microbes (Wyneken et al. 1988, Phillott \& Parmenter 2001, Wallace et al. 2011). While the relative contribution is unknown, potential bacterial (Craven et al. 2007) and fungal (Sarmiento-Ramírez et al. 2010) pathogens detected in sea turtle eggs may contribute to embryo death. Additionally, high microbial densities in organic-rich sand have been correlated with low $\mathrm{O}_{2}$ concentrations within the nest and with decreased hatching success (Bézy et al. 2015). Research attention in the area of microbial threats to sea turtle clutches has, however, focused on the fungal genus Fusarium, most notably, the Fusarium solani species complex (FSSC).

Commonly described as saprophytes, the FSSC contains both harmless varieties and strains recognized as emerging fungal pathogens that can impact crop plants, humans and other vertebrate and marine animals (e.g. shrimp, spiny lobster, clawed lobster, crayfish) (Lightner \& Fontaine 1975, Alderman 1981, McAleer \& Baxter 1983, Cawthorn 2011, Makkonen et al. 2013, Coleman 2016, Debourgogne et al. 2016, O'Donnell et al. 2016). While there have been numerous reports of $F$. solani being associated with sea turtle eggs (Phillott et al. 2004, Güçlü et al. 2010, Neves et al. 2015), fungal identification has historically relied on phenotype, making it difficult to know whether different studies detect the same FSSC members. Only recently have taxonomically informative genetic loci, principally the nuclear internal transcribed spacer (ITS) region, been sequenced from such isolates, allowing for their phylogenetic characterization and comparison. This approach enabled researchers to determine that FSSC cultures grown from unhatched eggs of 6 sea turtle species (loggerhead, green, hawksbill, olive ridley, leatherback and flatback) collected from geographically widespread nesting sites in the Atlantic, Indian and Pacific Oceans and the Caribbean Sea corresponded to $F$. keratoplasticum and F. falciforme (SarmientoRamírez et al. 2010, 2014a). As part of sea turtle management practices, recognizing the impact of fungal infection is part of a multifaceted effort to identify as many threats as possible that could decrease hatch- ing success. Maximizing offspring production is an important component of recovery in endangered and threatened populations. Indeed, the identification of factors influencing sustained hatchling production was cited by an international group of 35 sea turtle biologists as one of the key research areas needed for management and conservation of sea turtles (Rees et al. 2016).

The southeastern USA is the most important nesting area for loggerhead sea turtles Caretta caretta in North America. While the majority of nests occur in Florida, Georgia is part of the northern recovery unit (Florida/Georgia border to southern Virginia), which has been determined to be a genetically distinct subpopulation (Bowen et al. 2005, Shamblin et al. 2011) and the second largest loggerhead nesting aggregation in the northwest Atlantic (NMFS and USFWS 2008). Loggerheads from these nesting beaches have been found throughout the Atlantic Ocean and Mediterranean Sea (Bowen 2003). The management practices and health of this region have broad implications.

Despite recent increases in annual nest numbers, hatching success in Georgia is still much lower, 64.6\% (2009-2016 average, Georgia Department of Natural Resources, unpubl. data), than the worldwide average of $80 \%$ (Miller et al. 2003). Loggerhead nesting occurs throughout the 14 major barrier islands that line the Georgia coast. Among these, Jekyll Island has had comparatively low mean hatching success (61.0\% 2009-2016 average, Georgia Sea Turtle Center, unpubl. data). Consequently, this island has been the focus of research to determine the degree to which microbes contribute to embryo death and to characterize the types of microbes that infect loggerhead eggs (Craven et al. 2007, AwongTaylor et al. 2008). One reason for a bacterial focus had been the observation of pigmented fluid and biofilms within unhatched eggs. However, similar pigmentation has implicated fungi, principally FSSC members, in sea turtle embryo mortality (SarmientoRamírez et al. 2010, 2014a, Phillott \& Parmenter 2014).

Surveys of fungi associated with sea turtle eggs have universally been cultured based. While this approach has advantages, it is well established that culturing can drastically underestimate the richness of environmental fungi (Anderson \& Cairney 2004, O'Brien et al. 2005, Fierer et al. 2007). Fungal types can defy cultivation if the medium lacks required growth factors or if they are outcompeted by fastergrowing microbes. Therefore, as our primary goal in the present study, we adopted a strictly cultureindependent approach. We hypothesized that this 
would reveal novel fungi not previously detected in sea turtle eggs. Fungal DNA extracted from the embryonic fluid of unhatched eggs was subjected to PCR amplification and sequencing of the fungal ITS nuclear ribosomal DNA (nrDNA). The second goal was to examine the distribution of fungal types among nesting locations. Unhatched loggerhead eggs were examined from different regions of Jekyll Island, GA, over 2 nonconsecutive nesting seasons. Our results reveal that the FSSC members F. keratoplasticum and $F$. falciforme were the dominant fungal types in both nesting years and in all surveyed regions of Jekyll Island. This study provides cultivationindependent evidence to support the predominance of these fungi within unhatched sea turtle eggs. This research also represents, to the best of our knowledge, the first study documenting the presence of F. keratoplasticum and F. falciforme in North American loggerhead nests.

\section{MATERIALS AND METHODS}

In 2010 and 2012, unhatched eggs were collected from Jekyll Island, GA, loggerhead nests that had completed incubation. Unhatched eggs were collected from the northern (13 eggs; 3 nests), central (33 eggs; 6 nests) and southern (27 eggs; 5 nests) areas of the island. The coastline of Jekyll Island is divided into kilometer markers. In our study, KM 0-2 corresponds to the northern end of the island, which is erosional and minimally used as nesting habitat for sea turtles. The central section of the island (KM 6-11) is adjacent to the most developed region and is frequented by beachgoers. The southern end of Jekyll Island (KM 12-15) is considered the most pristine region and is characterized by undisturbed primary and secondary dunes, providing ideal nesting habitat. Nests that were deposited in a location on the beach determined to be threatened by humans or the tide were relocated. Relocated nests were excavated using gloved hands from the original nest within $6 \mathrm{~h}$ of deposition and moved to a hand-made simulated nest chamber approximately $3 \mathrm{~m}$ higher on the beach.

Clutches went to full term (50-60 d) and eggs were collected 3-5 d after hatchling emergence was confirmed or after $70 \mathrm{~d}$ incubation. Eggs were collected aseptically with gloved hands and stored individually in sterile Whirl-Pak sample bags (Nasco). Collected eggs were stored on ice for transport; upon returning to the laboratory (typically $2-5 \mathrm{~h}$ post-collection), the eggs were either immediately processed or main- tained at $-80^{\circ} \mathrm{C}$ until analysis. Eggs were surface sanitized using $\mathrm{H}_{2} \mathrm{O}_{2}, 95 \%$ ethanol and Betadine (Craven et al. 2007). An incision was made in the shell to extract embryonic fluid; all tools used for fluid extraction were sterilized.

A minimum of 5 eggs was analyzed per nest, unless nests contained fewer unhatched eggs. Genomic DNA was extracted from replicate embryonic fluid samples using the DNeasy Blood and Tissue Kit (Qiagen) and quantified using a NanoDrop 2000c UV-Vis Spectrophotometer (ThermoScientific). For each egg, 15 ng of DNA served as a template to PCR amplify the ITS nrDNA region using primers that specifically target fungi (ITS5F: 5' GGA AGT AAA AGT CGT AAC AAG G 3' and ITS4Rev: 5' TCC TCC GCT TAT TGA TAT GC 3') (White et al. 1990). Replicate DNA samples were PCR amplified. For each PCR run, a positive control (reaction contained fungal DNA) and a negative control (reaction contained no DNA to check for contamination) were included. Reactions were subjected to agarose gel electrophoresis $(1 \%)$ to confirm the presence of fungal DNA and verify controls. For each egg, replicate PCR products of the correct size ( $550 \mathrm{bp}$ ) were pooled and cloned using the TOPO TA Cloning Kit for Sequencing with One Shot TOP10 chemically competent Escherichia coli cells (Invitrogen). A library of ITS nrDNA fragments was generated for eggs that gave a positive fungal PCR result. The ITS fragments were sequenced by Functional Biosciences using an M13 (-20) primer (5' GTA AAA CGA CGG CCA GT 3'). Fungal ITS sequences were aligned and pairwise compared (Geneious Pro software); sequences having $\geq 99 \%$ identity were grouped as a single operational taxonomic unit (OTU). A representative sequence from each OTU was compared to GenBank DNA sequences using the software BLASTN (National Center for Biotechnology Information; www.ncbi.nlm.nih.gov/) to identify similar ITS sequences. ITS sequences were also subjected to phylogenetic analysis based on alignment of $\sim 468$ nucleotides using ClustalW (Geneious Pro software). Phylogenetic trees were generated based on distance analysis using neighbor joining with a Jukes-Cantor correction (TREECON package version 1.3b). Included were FSSC ITS reference sequences (soil, plant, animal and sea turtle isolates) used in the phylogenetic analysis conducted by Sarmiento-Ramírez et al. (2014a). All fungal ITS sequences recovered from this study have been deposited in the GenBank database at NCBI under accession numbers MF510538MF510814. 


\section{RESULTS}

Collectively, 72 unhatched eggs from 14 clutches ( $\mathrm{n}=36$ from 6 clutches [2010] and $\mathrm{n}=36$ from 8 clutches [2012]) were screened for the presence of fungi. Fungi were detected in $92.8 \%$ of the clutches, and $66.7 \%$ of the unhatched eggs $(50.0 \%$ in $2010 ; 83.3 \%$ in 2012) produced a fungal PCR product. The notemplate controls consistently failed to produce products, supporting that the fungi detected in unhatched eggs from Jekyll Island did not originate from extraneous DNA contaminating the reactions.

Fungal products from $75 \%$ of the positive samples were cloned, sequenced and analyzed; the results confirmed that the ITS sequences amplified corresponded only to those of fungi. Based on a $\geq 99 \%$ sequence identity threshold, 17 unique fungal OTUs were identified among the 267 egg sequences (Table 1). The ITS sequence of almost (95.5\%) every OTU was identical or nearly so ( $\geq 99 \%)$ to those of previously cultivated fungi. Members of both the Basidiomycetes and Ascomycetes were identified. However, the ascomycete Fusarium was by far the most frequently detected genus, occurring in $90.6 \%$ of all sequences (Table 1). The Fusarium sequences grouped into 4 OTUs, one corresponding to F. oxysporum, the others affiliating with the FSSC (O'Donnell 2000, Zhang et al. 2006). The FSSC was detected in $78.6 \%$ of clutches $(\mathrm{n}=14 ; 66.7 \%$ [2010] and $87.5 \%$ [2012]) and in $83.3 \%$ of eggs that tested positive for fungal ITS nrDNA.

The ITS nrDNA sequences of the 3 FSSC OTUs detected on Jekyll Island were nearly identical (>99\%) to those of the mortality-causing isolates described by Sarmiento-Ramírez et al. (2010, 2014a). Phylogenetic analysis supported the placement of the Jekyll Island FSSC sequences within the same $F$. falciforme and F. keratoplasticum-containing clades (Fig. 1). The only fungal groups detected in both nesting years were $F$. falciforme (OTU 1 and OTU 3) and F. keratoplasticum (OTU 2). Of the 2 FSSC types, F. falciforme was more frequently detected in clutches ( $57.1 \%$ versus $42.9 \%$ for $F$. keratoplasticum) and in eggs containing detectable levels of fungi $(58.3 \%$ versus $33.3 \%$ for F. keratoplasticum). Fusarium falciforme also represented the majority of amplified ITS sequences $(44.9 \%$ versus $29.2 \%$ for $F$. keratoplasticum). While $F$. oxysporum was not recovered in clutches surveyed in 2010, it was detected in $50 \%$ of the 2012 nests and $37.5 \%$ of the 2012 unhatched eggs with detectable levels of fungi. Among the remaining 13 non-Fusarium OTUs recovered, 12 were identified in only a single egg (Table 1).
Despite habitat differences in the Jekyll Island regions examined, unhatched eggs were commonly contaminated with F. falciforme and/or F. keratoplasticum in northern $(54.5 \%)$, central $(50 \%)$ and southern $(61.1 \%)$ zones. A higher frequency of $F$. keratoplasticum was detected in unhatched eggs in the northern region $(54.5 \%$ versus $18.2 \%$ for $F$. falciforme), whereas $F$. falciforme was recovered more frequently in eggs collected in the south $(55.6 \%$ versus $11.1 \%$ for F. keratoplasticum). Both FSSC groups were detected to a similar extent in central region eggs $(36 \%$ versus $20 \%$ for F. falciforme and F. keratoplasticum respectively). Fungal sequences from clutches in the central and southern beaches were also positive for $F$. oxysporum in 2012, but this species was not recovered from eggs collected in the north. Of the 14 clutches examined, 4 were relocated. Fusarium keratoplasticum and F. falciforme were detected in $100 \%$ of the relocated nests and in $70 \%$ of the in situ nests.

Due to the protected status of loggerhead sea turtles and permit restrictions, live control eggs were not actively sampled for this study. However, one loggerhead egg that had incubated a full $70 \mathrm{~d}$ unexpectedly contained a live embryo which did not survive. As with the other egg samples, DNA was extracted from the embryonic fluid, and fungal ITS PCR products were generated (contamination controls were clean). The fungal composition within this live egg completely differed from that of the other unhatched eggs (Table 1). In the live egg, Fusarium sequences were not detected and the 5 OTUs recovered did not overlap with those recovered in the other unhatched eggs.

\section{DISCUSSION}

This is the first study to survey the fungal composition of unhatched sea turtle eggs using a strictly molecular-based approach. Because prior research in this area identified fungal types by cultivation, it was possible that key groups went undetected if they failed to grow or were outcompeted in the chosen culture conditions (Anderson \& Cairney 2004). However, a direct DNA extraction, followed by PCR, recovered ITS sequences corresponding to those of previously cultivated fungi, suggesting that fungal characterization in sea turtle eggs by culturing is not significantly biased. Furthermore, the evidence presented in the present study supports the cultivation-based findings that specific Fusarium species are commonly found in sea turtle 


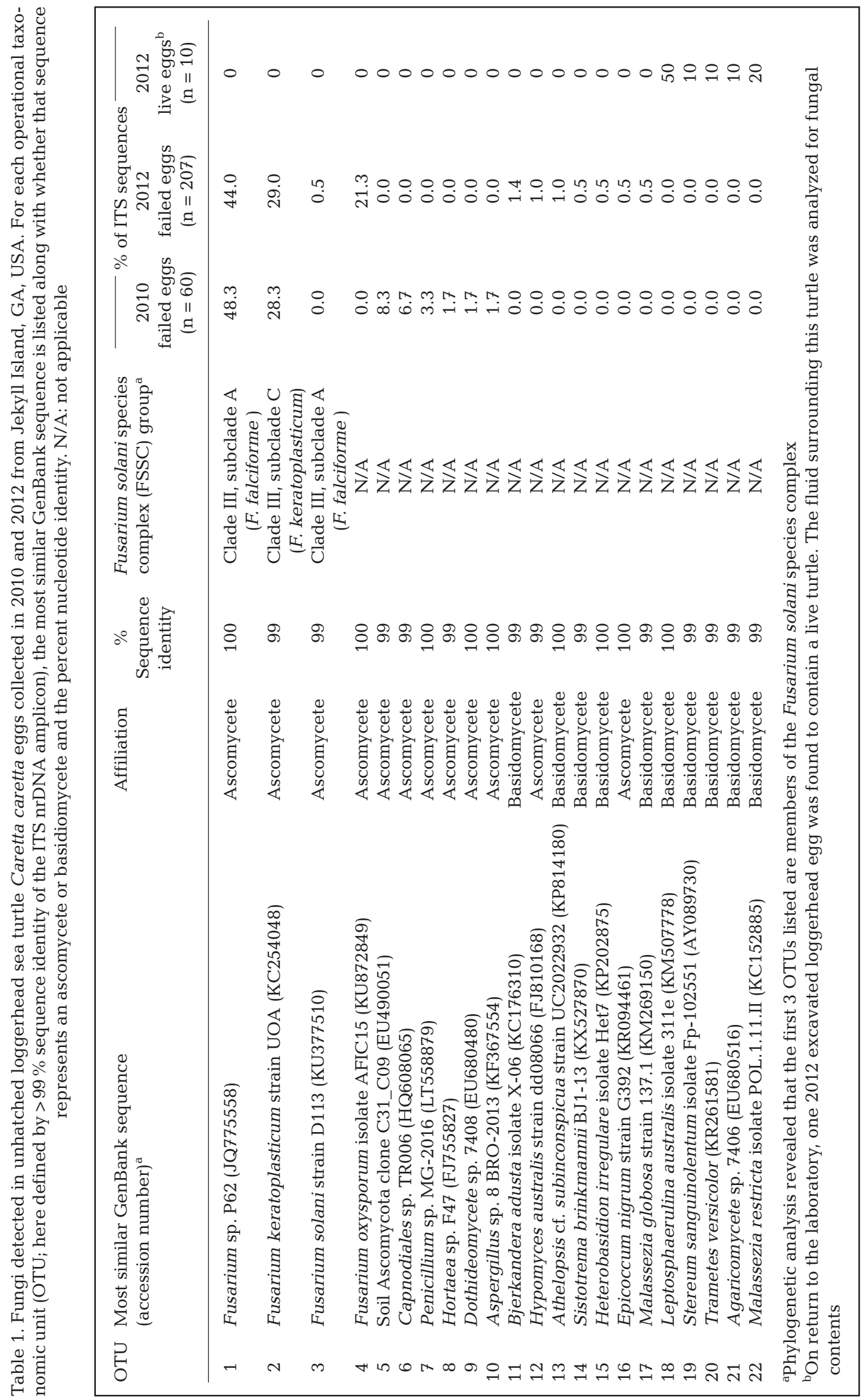




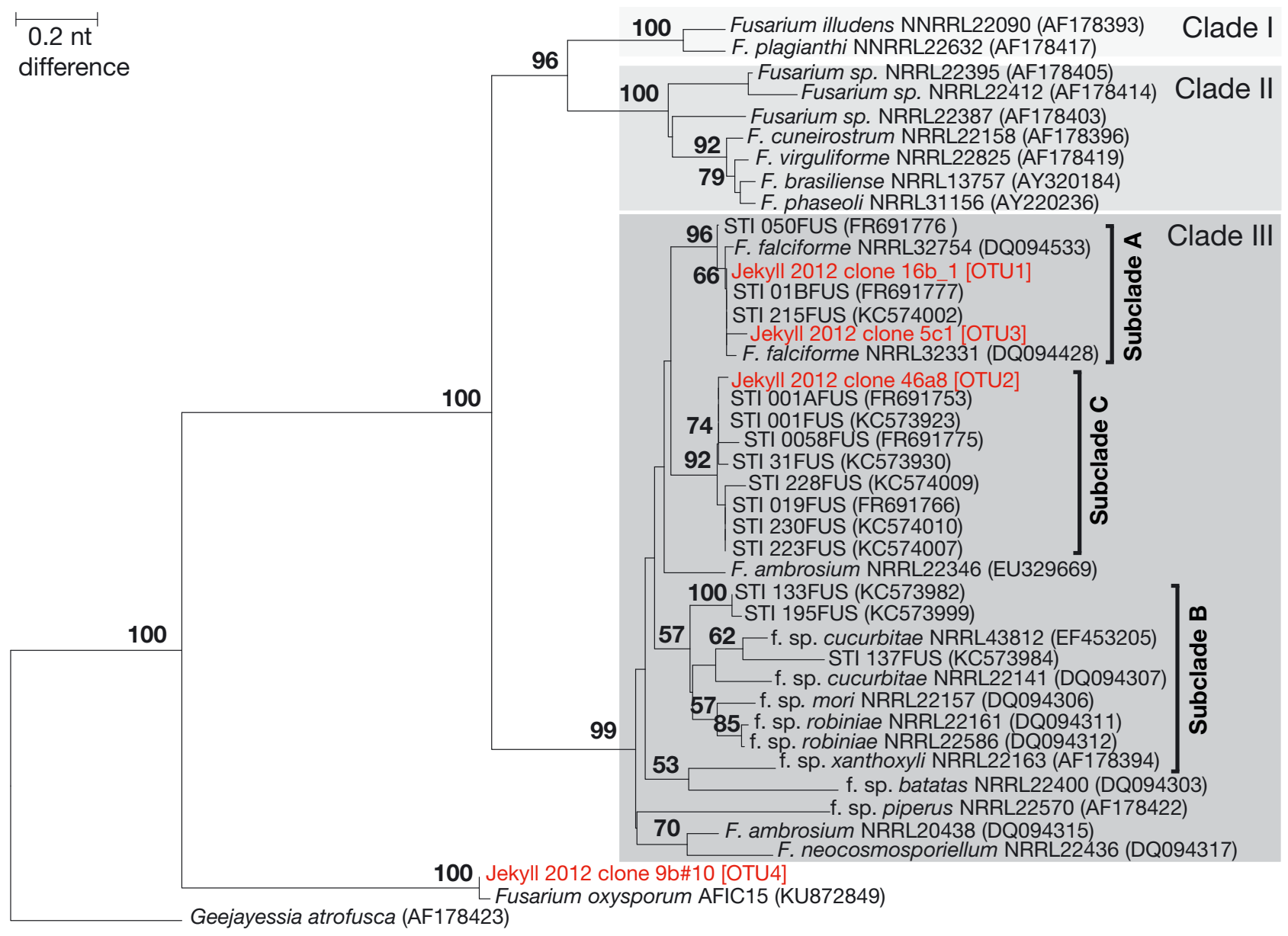

Fig. 1. Dendrogram ( 468 nt) displaying inferred phylogenetic relationships among Fusarium ITS nrDNA sequences. One representative from each Fusarium OTU (99\% nucleotide identity) recovered in this study is displayed in red. The portion of the tree with the grey backdrop corresponds to representatives from the Fusarium solani species complex (FSSC), clades I, II and III. Sequence names beginning with STI correspond to FSSC isolates cultured from unhatched loggerhead sea turtle eggs reported in Sarmiento-Ramírez et al. (2014a). GenBank accession numbers for each sequence are indicated in parentheses. Node numbers correspond to bootstrap values $>50 \%$ based on 100 replicates. Geejayessia atrofusca ITS nrDNA was used to root the tree

eggs (Sarmiento-Ramírez et al. 2010, 2014a, Neves et al. 2015). Adoption of molecular surveys to detect Fusarium in field samples has the advantage of not requiring propagation of potentially pathogenic, spore-forming microbes. Molecular-based approaches are also practical for elucidating microbial community composition in large-scale studies, in samples that cannot be immediately processed and in high-diversity samples. For instance, PhyloChip hybridization of $16 \mathrm{~S}$ rDNA amplicons was recently used to determine the dominant bacterial phyla inhabiting hawksbill sea turtle Eretmochelys imbricata eggs (Sarmiento-Ramírez et al. 2014b). However, the congruence of fungal constituents identified here with those identified by cultivation suggests that lower cost and less technically deman- ding cultivation approaches are sufficient to detect the primary fungi associated with sea turtle eggs.

During the nesting seasons surveyed unhatched loggerhead sea turtle eggs on Jekyll Island commonly contained fungi, with Fusarium species dominating the types recovered. To the best of our knowledge, this represents the first documentation of the FSSC within North American loggerhead sea turtle eggs. Ubiquitous in soil and on decomposing organic matter, FSSC members were long referred to as simply $F$. solani in the scientific literature (O'Donnell et al. 2016), before an extensive phylogenetic characterization (O'Donnell et al. 2008) revealed this morphospecies to comprise at least 60 species that form 3 clades. Identification of FSSC members often involves analysis of up to 3 genetic loci: (1) ITS nrDNA 
plus the 28S rRNA gene, (2) the elongation factor $1 \alpha$ gene and (3) RPB2 (encodes for a RNA polymerase II subunit) (O'Donnell et al. 2008, Schroers et al. 2016). Sarmiento-Ramírez et al. (2014a) used both Bayesian and maximum parsimony to determine that their Fusarium sea turtle isolates clustered within FSSC clade III, subclade A (referred to as Fusarium falciforme) and FSSC clade III, subclade C (referred to as Fusarium keratoplasticum). This multi-loci analysis, based on the ITS nrDNA-28S and RPB2 loci, was congruent with the phylogeny based on ITS nrDNA alone (Sarmiento-Ramírez et al. 2014a). FSSC isolates cultured from green sea turtle eggshells were subsequently identified based on ITS nrDNA phylogenetic analysis (Sarmiento-Ramírez et al. 2017); a similar approach was taken here. In our study, F. falciforme and F. keratoplasticum reference sequences clustered with their established FSSC clades at high bootstrap values (Fig. 1). This suggests confidence in our identification approach and links FSSC members detected here with isolates recovered in sea turtle eggs throughout the world.

The recovery and dominance of $F$. falciforme and $F$. keratoplasticum in Jekyll Island unhatched loggerhead sea turtle eggs is consistent with their detection in the eggs of 6 sea turtle species in Australia, Ecuador, Ascension Island, Boa Vista Island, Columbia, Ecuador, Costa Rica and Puerto Rico (SarmientoRamírez et al. 2014a, 2017, Rosado-Rodríguez \& Maldonado-Ramírez 2016). Accompanying physical characteristics, including the appearance of black and/or red spots on the affected eggs, as described in Phillott \& Parmenter (2012) and Sarmiento-Ramírez et al. (2014a), were often observed on the loggerhead eggs collected in this study. These fungi were recovered from each region of Jekyll Island surveyed and in both nesting seasons. A compelling case has been made that $F$. falciforme and $F$. keratoplasticum represent pathogens of sea turtle embryos as opposed to simply being saprophytic. An inoculation experiment applying Koch's postulates demonstrated that an unhatched sea turtle egg isolate of F. keratoplasticum can cause disease and death in loggerhead embryos (Sarmiento-Ramírez et al. 2010). In the field, clutch mortality rates were correlated with incidence of eggs displaying physical signs (colored spots) attributed to FSSC infection (Sarmiento-Ramírez et al. 2014a). Furthermore, the optimal growth temperatures for FSSC sea turtle isolates coincide with nest conditions.

F. oxysporum represented the only other fungal type prevalent in the Jekyll Island eggs examined. As with F. solani, F. oxysporum represents a diverse species complex containing strains causing vascular wilt disease in a wide range of plants (Beckman 1987) and opportunistic infections in humans and marine animals, including dolphins (Staggs et al. 2010). While it has been cultured from sea turtle eggs (Phillott et al. 2004, Neves et al. 2015), F. oxysporum has not been established as a sea turtle pathogen. Fusarium species were not detected in the one 'control' egg analyzed in this study. This is consistent with the Cape Verde study (Sarmiento-Ramírez et al. 2010), which found a lower incidence of FSSC in live eggs. Detection of other fungal types here was limited to a single egg (Table 1). This included Aspergillus and Penicillium; members have been previously cultivated from sea turtle eggs and certain strains produce mycotoxins (Elshafie et al. 2007, Güçlü et al. 2010). However, the low incidence implies that these groups are unlikely to pose a major threat to hatching success on Jekyll Island.

While the findings presented here clearly establish the high prevalence of $F$. falciforme and $F$. keratoplasticum in the unhatched loggerhead eggs examined, their impact on hatching success in this system remains unknown. These FSSC groups were detected in nests that had both high and low hatch success. While these specific fungi can infiltrate loggerhead eggs, they may only contribute to embryo death in certain situations (e.g. if they reach high densities within the egg or nest [Phillott 2004], if the embryo is stressed and/or if other pathogenic microbes are present). Environmental factors may also affect risk; for instance, beaches having high silt/clay content and frequent tidal inundation have been correlated with higher incidence of Fusarium-related disease and loggerhead embryo mortality (SarmientoRamírez et al. 2014a). The source of F. falciforme and F. keratoplasticum is also unclear. Microbes present within the eggs could originate from the mother (i.e. oviduct or cloacae) or the sand. Given that Fusarium species are commonly associated with soil and plant matter and that the cloacal mucus has antifungal properties (Phillott \& Parmenter 2012), the latter seems more likely. While both fungi were detected throughout the study site, F. falciforme was more prevalent in eggs collected from the southern end of Jekyll Island, considered its most pristine region. F. keratoplasticum was more frequently recovered from eggs at the north end, a region subject to erosion and adjacent to St. Simons Sound, which is part of a shipping channel extending from the port of Brunswick, GA, to the Atlantic Ocean. A recent survey of green sea turtle eggs on Ascension Island noted a similar trend: F. keratoplasticum and F. falciforme were most frequently cultivated from regions 
having relatively high and low human activity, respectively (Sarmiento-Ramírez et al. 2017). Additional studies examining the environmental factors driving the distribution of these fungi are clearly needed.

While it is not known whether F. falciforme and $F$. keratoplasticum contribute directly to loggerhead embryo death on Jekyll Island, the similarity to fungi implicated in sea turtle embryo disease is striking. Research efforts should focus on characterizing these fungi, their virulence factors, and the parameters that impact their abundance and distribution, including whether nest relocation or other management practices increase the risk of exposing eggs to FSSC members. Interestingly, FSSC groups were detected more frequently in relocated than in in situ nests, though it is important to note that the number of relocated nests examined in this study was low $(n=4)$. Current investigations are examining the oviductal/cloacal contributions to the microbes within the nest environment as well as a comprehensive evaluation of nest sand. The distribution of F. falciforme and F. keratoplasticum on sea turtle nesting beaches worldwide has been documented through a broad sampling effort (SarmientoRamírez et al. 2014a). The North American continent and Western North Atlantic basin can now be confirmed as locations found positive for FSSC infection of loggerhead sea turtle nests.

Acknowledgements. We acknowledge Mark Dodd and the Georgia Department of Natural Resources (DNR), The Jekyll Island Authority, Catherine Ridley, Kimberly Andrews, Terry Norton and The Georgia Sea Turtle Center for their cooperation. We thank all of the former Armstrong State University undergraduate research assistants and students who participated and helped with this project, most notably Anthony 'Apple' Hawkins. This research was conducted under scientific permits for research on endangered species from the Georgia Department of Natural Resources and the United States Fish and Wildlife Service. This research was funded by Armstrong State University (ASU), ASU College of Science and Technology and ASU Department of Biology.

\section{LITERATURE CITED}

Alderman DJ (1981) Fusarium solani causing an exoskeleton pathology in cultured lobsters, Homarus vulgaris. Trans Br Mycol Soc 76:25-27

Anderson IC, Cairney JWG (2004) Diversity and ecology of soil fungal communities: increased understanding through the application of molecular techniques. Environ Microbiol 6:769-779

Anderson PK, Cunningham AA, Patel NG, Morales FJ, Epstein PR, Daszak P (2004) Emerging infectious diseases of plants: pathogen pollution, climate change and agrotechnology drivers. Trends Ecol Evol 19:535-544

* Awong-Taylor J, Craven KS, Griffiths L, Bass C, Muscarella $M$ (2008) Comparison of biochemical and molecular methods for the identification of bacterial isolates associated with failed loggerhead sea turtle eggs. J Appl Microbiol 104:1244-1251

Beckman CH (1987) The nature of vascular wilt diseases of plants. APS Press, St Paul, MN

Bézy VS, Valverde RA, Plante CJ (2015) Olive ridley sea turtle hatching success as a function of microbial abundance and the microenvironment of in situ nest sand at Ostional, Costa Rica. PLoS ONE 10:e0118579

Bowen BW (2003) What is a loggerhead turtle? The genetic perspective. In: Bolten $\mathrm{AB}$, Witherington BE (eds) Loggerhead sea turtles. Smithsonian Books, Washington, DC, $p$ 7-27

* Bowen BW, Bass AL, Soares L, Toonen RJ (2005) Conservation implications of complex population structure: lessons from the loggerhead turtle (Caretta caretta). Mol Ecol 14:2389-2402

* Cawthorn RJ (2011) Diseases of American lobsters (Homarus americanus): a review. J Invertebr Pathol 106:71-78

Coleman JJ (2016) The Fusarium solani species complex: ubiquitous pathogens of agricultural importance. Mol Plant Pathol 17:146-158

Craven KS, Awong-Taylor J, Griffiths L, Bass C, Muscarella $M$ (2007) Identification of bacterial isolates from unhatched loggerhead (Caretta caretta) sea turtle eggs in Georgia, USA. Mar Turtle Newsl 115:9-11

* Debourgogne A, Dorin J, Machouart M (2016) Emerging infections due to filamentous fungi in humans and animals: only the tip of the iceberg? Environ Microbiol Rep 8:332-342

Elshafie A, Al-Bahry SN, Al-Kindy AY, Ba-Omar T, Mahmoud I (2007) Mycoflora and aflatoxins in soil, eggshells, and failed eggs of Chelonia mydas at Ras Al-Jins, Oman. Chelonian Conserv Biol 6:267-270

Eskew EA, Todd BD (2013) Parallels in amphibian and bat declines from pathogenic fungi. Emerg Infect Dis 19: 379-385

Fierer N, Breitbart M, Nulton N, Salamon P and others (2007) Metagenomic and small-subunit rRNA analyses reveal the genetic diversity of bacteria, archaea, fungi, and viruses in soil. Appl Environ Microbiol 73:7059-7066

* Fisher MC, Henk DA, Briggs CJ, Brownstein JS, Madoff LC, McCraw SL, Gurr SJ (2012) Emerging fungal threats to animal, plant and ecosystem health. Nature 484:186-194

Gleason FH, Gadd GM, Pitt JI, Larkum AWD (2017) The roles of endolithic fungi in bioerosion and disease in marine ecosystems. II. Potential facultatively parasitic anamorphic ascomycetes can cause disease in corals and molluscs. Mycology 8:216-227

Güçlü Ö, Biyik H, ahinet A (2010) Mycoflora identified from loggerhead turtle (Caretta caretta) eggshells and nests at Fethiye Beach, Turkey. Afr J Microbiol Res 4:408-413

Lightner DV, Fontaine CT (1975) A mycosis of the American lobster, Homarus americanus, caused by Fusarium sp. J Invertebr Pathol 25:239-245

Makkonen J, Jussila J, Koistinen J, Paaver T, Hurt M, Kook H (2013) Fusarium avenaceum causes burn spot disease syndrome in noble crayfish (Astacus astacus). J Invertebr Pathol 113:184-190

McAleer R, Baxter M (1983) Black shell disease of the western rock lobster caused by Fusarium solani. Proc Int Soc Human Anim Mycol 34:378-382 
Miller J, Limpus CJ, Godfrey M (2003) Nest site selection, oviposition, eggs, development, hatching and emergence of loggerhead turtles. In: Bolten $A B$, Witherington BE (eds) Loggerhead sea turtles. Smithsonian Books, Washington, DC, p 125-143

Neves MSC, de Melo Moura CC, de Oliveira LG (2015) Mycobiota from the eggs, nests and stillbirths of Eretmochelys imbricata Linneus 1766 (Testudines: Cheloniidae) in Pernambuco State, Brazil. Afr J Microbiol Res 9:1195-1199

NMFS and USFWS (National Marine Fisheries Service and US Fish and Wildlife Service) (2008) Recovery plan for the northwest Atlantic population of the loggerhead sea turtle (Caretta caretta), 2nd revsn. National Marine Fisheries Service, Silver Spring, MD

O'Brien HE, Parrent JL, Jackson JA, Moncalvo JM, Vilgalys R (2005) Fungal community analysis by large-scale sequencing of environmental samples. Appl Environ Microbiol 71:5544-5550

O'Donnell K (2000) Molecular phylogeny of the Nectria haematococca-Fusarium solani species complex. Mycologia 92:919-938

O'Donnell K, Sutton DA, Fothergill A, McCarthy D and others (2008) Molecular phylogenetic diversity, multilocus haplotype nomenclature and in vitro antifungal resistance within the Fusarium solani species complex. J Clin Microbiol 46:2477-2490

O'Donnell K, Sutton DA, Wiederhold N, Robert V, Crous PW, Geiser DM (2016) Veterinary fusarioses within the United States. J Clin Microbiol 54:2813-2819

Phillott AD (2004) Penetration of the eggshell and invasion of embryonic tissue by fungi colonizing sea turtle eggs. Herpetofauna 34:44-47

Phillott AD, Parmenter CJ (2001) The distribution of failed eggs and the appearance of fungi in artificial nests of green (Chelonia mydas) and loggerhead (Caretta caretta) sea turtles. Aust J Zool 49:713-718

Phillott AD, Parmenter CJ (2012) Anti-fungal properties of sea turtle cloacal mucus and egg albumin. Mar Turtle Newsl 134:17-21

Phillott AD, Parmenter CJ (2014) Fungal colonization of green sea turtle (Chelonia mydas) nests is unlikely to affect hatchling condition. Herpetol Conserv Biol 9:297-301

Phillott AD, Parmenter CJ, Limpus CJ (2004) Occurrence of mycobiota in eastern Australian sea turtle nests. Mem Queensl Mus 49:701-703

Rees AF, Alfaro-Shigueto J, Barata PCR, Bjorndal KA and others (2016) Are we working towards global research priorities for management and conservation of sea turtles? Endang Species Res 31:337-382

Rosado-Rodríguez G, Maldonado-Ramírez SL (2016) Myce-

Editorial responsibility: Mark Hamann,

Townsville, Queensland, Australia lial fungal diversity associated with the leatherback sea turtle (Dermochelys coriacea) nests from Western Puerto Rico. Chelonian Conserv Biol 15:265-272

* Sarmiento-Ramírez JM, Abella E, Martin MP, Telleria MT, Lopez-Juardo LF, Marco A, Dieguez-Uribeondo J (2010) Fusarium solani is responsible for mass mortalities in nests of loggerhead sea turtle Caretta, in Boavista, Cape Verde. FEMS Microbiol Lett 312:192-200

* Sarmiento-Ramírez JM, Abella-Perez E, Phillott AD, Sim J and others (2014a) Global distribution of two fungal pathogens threatening endangered sea turtles. PLOS ONE 9:e85853

Sarmiento-Ramírez JM, van der Voort M, Raaijmakers JM, Dieguez-Uribeondo J (2014b) Unraveling the microbiome of eggs of the endangered sea turtle Eretmochelys imbricata identifies bacteria with activity against the emerging pathogen Fusarium falciforme. PLOS ONE 9: e95206

* Sarmiento-Ramírez JM, Sim J, West PV, Dieguez-Uribeondo $J$ (2017) Isolation of fungal pathogens from eggs of the endangered sea turtle species Chelonia mydas in Ascension Island. J Mar Biol Assoc UK 97:661-667

Schroers HJ, Samuels GJ, Zhang N, Short DPG, Juba J, Geiser DM (2016) Epitypification of Fusisporium (Fusarium) solani and its assignment to a common phylogenetic species in the Fusarium solani species complex. Mycologia 108:806-819

Shamblin BM, Dodd MG, Bagley DA, Ehrhart LM and others (2011) Genetic structure of the southeastern United States loggerhead turtle nesting aggregation: evidence of additional structure within the peninsular Florida recovery unit. Mar Biol 158:571-587

Staggs L, St Leger J, Bossart G, Townsend FL Jr, Hicks C, Rinaldi M (2010) A novel case of Fusarium oxysporum infection in an Atlantic bottlenose dolphin. J Zoo Wildl Med 41:287-290

WWallace BP, DiMatteo AD, Bolton AB, Chaloupka MY and others (2011) Global conservation priorities for marine turtles. PLOS ONE 6:e24510

White TJ, Bruns T, Lee S, Taylor JW (1990) Amplification and direct sequencing of fungal ribosomal RNA genes for phylogenetics. In: Innis MA, Gelfand DH, Sninsky JJ, White TJ (eds) PCR protocols: a guide to methods and applications. Academic Press, New York, NY, p 315-322

*Wyneken J, Burke TJ, Salmon M, Pederson DK (1988) Egg failure in natural and relocated sea turtle nests. J Herpetol 22:88-96

* Zhang N, O'Donnell K, Sutton DA, Nalim FA and others (2006) Members of the Fusarium solani species complex that cause infections in both humans and plants are common in the environment. J Clin Microbiol 44:2186-2190

Submitted: July 26, 2017; Accepted: April 12, 2018

Proofs received from author(s): June 5, 2018 